\title{
A Small Discipline, Scarce Publicity, and Compromised Outward Reach: The Advisory Roles of Political Scientists in France
}

\author{
Pierre Squevin and David Aubin
}

\subsection{INTRODUCTION}

Although its origins date back to the latter half of the nineteenth century, with the creation of a Free School of Political Sciences in Paris (Favre, 1989), French political science became established as a discipline in its own right in the years following WWII. A key moment in its foundation was the period 1948-1949 when the French Association of Political Science (AFSP) was constituted (Déloye \& Mayer, 2008). Since then, studies have focused on the evolutionary patterns characterizing French political science (Gaïti \& Scot, 2017; Déloye \& Mayer, 2019). What stands out from these studies is French political science's slow development and lack of a legal framework until the late 1960s. This early period

P. Squevin $(\bowtie) \bullet$ D. Aubin

UCLouvain, Ottignies-Louvain-la-Neuve, Belgium

e-mail: pierre.squevin@uclouvain.be

(C) The Author(s) 2022

M. Brans, A. Timmermans (eds.), The Advisory Roles of Political

Scientists in Europe, https://doi.org/10.1007/978-3-030-86005-9_7 
in its development was followed by a period of more sustained growth and expansion in the 1970s and 1980s, when it became the more firmly established, professionalized, mature discipline that it is now (Smith, 2020). More specifically, some studies have looked at the internationalization of French political science (Boncourt, 2011) or the publication strategies of French political scientists (Grossman, 2010), while others have questioned the peculiarities and the emergence on the national scene of sub-disciplines such as international relations (Cornut \& Battistella, 2013) and policy studies (Boussaguet et al., 2015; Halpern et al., 2018; Le Galès, 2011).

French political science is capable of self-reflection and as such regularly questions its own existence and significance. Despite efforts to retrace the development of the discipline, and notwithstanding certain signs of selfcriticism among its members, limited attention has been paid to the role of French political scientists as advisers, experts, or relevant knowledge producers in their own right. Also owing to a lack of transparency and scarce evidence to date, little is known about the advisory roles of French political scientists. This issue has been raised on several occasions: the silence of the discipline has been denounced (Favre, 2005); there have been manifestations of autonomist tendencies (Spenlauer, 1999) together with demonstrations of the ambivalent, complex interdependencies between social sciences (including political science) and the State (Bezès et al., 2005; Lacouette-Fougère \& Lascoumes, 2013). One chapter of a volume published in 2018 hinted at the advisory role of political science and other social science disciplines and suggested that there was a gradual, albeit still minimal, bridging of the gap between academic research in the field of policy analysis and the practice of policy analysis itself (Le Galès \& Hassenteufel, 2018).

Following on from such earlier reflections and partial conclusions, this chapter seeks to shed more light on the degree and types of involvement of French political scientists in advisory activities. Using a tailor-made typology, their advisory profiles will be disclosed and placed in context. This chapter also aims to reveal who the recipients of advice are, and how advice is delivered, and then goes on to explore the range of advisory content and formats. Normative attitudes towards advice-giving are also discussed, as is the participation of academics in public debate. The basis for this analysis is constituted by data on France taken from a European-wide survey of political scientists conducted in 2018. These data are 
complemented by 14 interviews with French political scientists in nearly all the relevant sub-disciplines, carried out between January and February 2019.

First, a description of the French policy advisory system is given, which also covers the position of political scientists within the national policy advisory system and the operation of that system. The chapter then focuses on political science as a discipline and on the ways in which its characteristics may condition the development of advisory roles. After presenting the sample of political scientists taken from the survey, a descriptive analysis will be conducted, and the findings of such examined in order to better understand the advisory roles taken up by France's political scientists. A case study of a recent public debate on institutional reforms of parliament is used to illustrate how the advisory activities of political scientists in France may develop.

\subsection{The Position of Political Scientists Within the French Policy Advisory System}

The initial part of this section will present the characteristics of the policy advisory system in France and the place of political scientists within that system. There are indeed clear tendencies at work hindering French political scientists' involvement in advisory activities, but these may be in part offset by the presence of more integrative mechanisms. The second part of this section specifies the available access points through which political scientists' advice can flow and find its way to the country's policymakers.

\subsubsection{Characteristics of the French Policy Advisory System}

The most stable and characteristic feature of the French policy advisory system is statism. The roots of statism go back far in history to before the French Revolution. In its current form, statism entails the State acting as the dominant, omnipresent player within the country's policy advisory systems. The French State exerts considerable control over policy-making processes at all levels, and the intervention of central government is an intense, constant feature of many areas of economic and social life, despite more recent decentralization and privatization processes (Bezès \& Le Lidec, 2011). 
Statism as a form of interest intermediation has reinvented itself and remains a key feature of the national system (Woll, 2009). The best way to secure a prominent position in the policy advisory system of France is to be recognized as an expert or analyst by state actors, and in particular the central decision-making milieu comprising political insiders and senior civil servants (Grémion, 1982). Central decision-makers establish the inputs needed from other insiders, and also from stakeholders, societal groups, and possibly from academics. They exercise the gate-keeping power by which to silence, short-circuit, or reframe social demands.

At the same time, relations between the public administration and academic organizations are made difficult by the characteristics of the French administrative system. Indeed, the functioning of the policy advisory system is conditioned by a Napoleonic (or Bonapartist) administrative tradition that has survived to this day (Ongaro, 2010; Painter \& Peters, 2010). In such a system, the State is seen as both unitary and organic. A strong and preeminent executive is supported by a civil service acting as the ultimate guardian of the general interest (Rosser \& Mavrot, 2017). Intimately linked to the Napoleonic administrative tradition, the involvement of intermediary bodies such as interest and public relations groups is still regarded with some suspicion in France (Schmidt, 1999). Hence, at least in principle, an independent, rather exclusive civil service enjoys considerable room for intervention in France's social fabric.

The importance of the central State in policy-making comes with the development of that State's general, multi-purpose expertise, which is needed to facilitate the management of public affairs on all fronts. This expertise has been referred to as State expertise, as opposed to, and usually distinguished from, other kinds such as lay or academic expertise (Hauchecorne \& Penissat, 2018). State expertise, which also encompasses policy analysis and evaluation, is often to be found in the 'grands corps', which are groups for the most part composed of senior career civil servants (Biland \& Gally, 2018). Those groups share common characteristics, due to their similar backgrounds and training (usually at the various 'grandes écoles'), their shared perception of the world, and their cohesion and 'esprit de corps'. One of their hallmarks is the ability to navigate between the worlds of politics, the civil service, and the private sector. They are key agents in the interpenetration of the (senior) civil service and politics that has characterized the Fifth Republic (de Baecque, 1981). When they do not have an elective mandate, these individuals usually hold senior positions in central or local administrations or as personal advisers to ministers 
and junior ministers, local and regional political elites, or major firms operating in the private or para-public sector. The broad expertise of the grand corps and senior civil servants can be of a technical or administrative nature and serves many purposes with regard to the running of the State. This sort of monopoly over expertise and knowledge production makes it very difficult for political science academics to bring their own expertise to bear on public policy.

Additionally, many French civil servants are not specifically trained in the social and political sciences, either in universities or in the grandes écoles. Political science still plays a minor role in their curricula and is often viewed as a generalist discipline, although it has been gaining ground as a result of recent attempts to include more courses on political sociology or policy studies in teaching programmes. Individuals' training consists mostly of the study of public law, economics and public management, public finance, budget and accounting, with regard to which they are required to pass specific exams. If novices entering France's public administration studied at one of the grandes écoles like the National School of Administration (ENA), then they were mainly taught by practitioners and professionals. Subsequently, they acquire their skills, professional knowledge, and expertise on the job through their direct involvement in public institutions.

Despite what appear to be impediments fundamentally related to the administrative regime and its enduring traditions, in practice outside actors such as academics, taken individually or collectively, are not entirely removed from advisory roles vis-à-vis the public administration. The sheer size of the public sector in the country, and the omnipresence of the bureaucracy, may mean that academics do in fact encounter civil servants for advisory purposes at least a few times during the course of their professional careers. Secondly, and perhaps more importantly in terms of advisory opportunities, the Napoleonic tradition means that co-option mechanisms are always in place to guarantee outsiders a minimum of access to, and inclusion in, the handling of public service matters. Such mechanisms are based on invitations sent to specific actors, whereby they are asked to help with, and play an instrumental part in, the resolution of those issues on the public agenda of the day (Painter \& Peters, 2010).

In addition to statism, another essential feature of the French policy advisory system is neo-corporatism. Although France is certainly not a typical (neo-)corporatist nation, some elements of neo-corporatism can be found in certain policy domains. Indeed, a 'corporatism à la française' was 
identified in the late 1980s within the domains of agriculture, social policy, and civil aviation, where stable, institutionalized arenas and coordination existed (Jobert \& Muller, 1987). This has even led some scholars to speak of meso-corporatism or sectoral corporatism in France (e.g. Hassenteufel, 1990; Szarka, 2002). For French political scientists, participating in the policy advisory system would mean having significant ties with the social partners ("partenaires sociaux') who are regularly involved in, and consulted on, the management of socio-economic issues.

Recent developments point to a move towards pluralism in interest intermediation and to the emergence of a participatory imperative (Grossman and Saurugger, 2004). Such a trend also shapes, or rather reshapes, the current French policy advisory system. An indicator of this dynamic is a surge in the number of 'associations', that is, of non-profit organizations (as specified under the law of 1901) embodying a wide range of aims (e.g. cultural, social, or interest representation). These social groups and civil society organizations are being increasingly consulted by public authorities during the policy-making process (Woll, 2009). They contribute to awareness of policy issues and participate in policy implementation by helping the concretization of policies and by spotting inconsistencies or bottlenecks in public policy solutions. Associations may also be active in the judicialization of policy-making. Yet, with regard to all of these aspects of their involvement, they do not enjoy equal weight; some play a more important role in local, regional, or national policy-makings, especially when they are officially recognized as 'non-profit organizations serving the public good' (associations reconnues d'utilité publique).

\subsubsection{Access Points and Venues for the Provision of Advice by Political Scientists}

As we move from the core, internal advisory system to its more peripheral or external components, several points of access can be identified; some of them seem harder to reach, such as ministerial offices, while others appear to offer real openings for political scientists to play a more important role, for example, in certain advisory bodies, consultative organs, or think tanks.

The internal advisory system revolves around various organizations and groups which may represent points of entry for the provision of political scientists' advice. In the French ministerial cabinet system, the flow of advice coming from, and circulating through, ministerial cabinets is highly significant. This also applies to the 'presidential' cabinet at the Elysée 
palace. Any guaranteed access to ministerial offices, especially in core ministries, automatically offers academics important connections. Access is ensured via formal hearings and consultation, or through informal meetings, which usually take place in Paris. Being officially appointed as a ministerial adviser is another way for a political scientist to enter senior executive circles, although sociographic research has shown that the number of cabinet personnel coming from the spheres of higher education and research is extremely limited (e.g. Bellon et al. 2018; Mathiot and Sawicki, 1999). During the Fifth Republic, only a handful of political scientists have succeeded in working within ministerial cabinets.

Advisory bodies, public consultancy organizations, and ad hoc committees must be considered as well. Although there are fewer advisory bodies in France than in many other countries (Schultz et al., 2015), several of them are quite active. Of these, the Economic, Social and Environmental Committee (CESE) deserves special attention. The CESE, operating as the third assembly of the French republic (after the National Assembly and the Senate), acts as the interface between organized, qualified civil society and policymakers (specifically, the executive and legislative branches of government), providing them with between 25 and 30 items of advice per year. 'Associate figures' may be handpicked by the government to operate for the five years of the CESE's term of office and sustain its work thanks to their expertise. Their number varies from around 50 to a maximum of 72. The nature of such advisory figures indicates the kind of individuals that the government of the day considers experts and whether political scientists are among them.

France Stratégie, which replaced the former Commissariat Général au Plan (National Planning Office) attached to the Prime Minister's office, dominates the internal advisory system. Countless smaller consultative organs also constitute potential access routes for political scientists. In September 2019, there were 394 consultative organs providing their services to the Prime Minister, government ministers, and the Bank of France, some of whom being more active than others (for an overview of advisory bodies, see https://www.vie-publique.fr/eclairage/22018-reforme-deletat-reduction-du-nombre-des-commissions-consultatives). Other higher or scientific councils, observatories, and commissions, like the Economic Analysis Council (CAE) and the Higher Council for Climate, are telling examples of organizations that the French State uses to (re-)internalize expertise. Although they must compete with more prominent and established disciplines within the policy advisory system, political scientists can 
be officially appointed as experts or 'qualified figures' within such organizations for a fixed period of time or be consulted more intermittently. There are a small number of such consultative organs dedicated to issues closer to political scientists' main concerns, in which they may play a key role, including the Scientific Council on Radicalization Processes (COSPRAD), the Inter-Ministerial Delegation against Racism, AntiSemitism and Anti-LGBT Hatred (DILCRAH), the Scientific Council of the Directorate-General of the Administration and Public Service (DGAFP), the National Observatory of Urban Policy (ONPV), and so on.

Another point of access can be found in the legislative branch of government, in particular the National Assembly and the Senate (Rozenberg \& Surel, 2018). Parliamentary commissions organize hearings and rounds of consultation with experts, who sometimes include political scientists. Political scientists are also quoted in, or engaged in the writing of, reports ordered by, or addressed to, members of the different assemblies, sometimes within the context of information/fact-finding missions. In 2008, in an attempt to reinforce its powers, a constitutional amendment endowed parliament with new powers regarding the evaluation of public policy. This opened up opportunities for French policy scholars and scholars of democracy and institutions to become involved in parliamentary work.

Nevertheless, the aforementioned presence of the grands corps-the historical development of a particularly strong in-house advisory system with its own capacity to generate expertise within the different branches of government-does not prevent peripheral actors from external lay or academic arenas from also being active in policy advisory systems.

In this respect, consultancy has been on the rise in France as well as elsewhere (Gervais and Pierru, 2018). Studies have shown that consultancy firms participate in the production and diffusion of specific ideas and approaches, such as that of New Public Management (e.g. Bezès, 2012). Political scientists will have been little affected, since they likely benefit only marginally from the outsourcing of advice provision to such consultancy firms.

Think tanks also appeared, to some extent, as external arenas of socialization and formulators of analyses and ideas (Berrebi-Hoffmann \& Grémion, 2009). Many think tanks rely more or less extensively on the knowledge of political scientists, who, for example, are offered the opportunity to express themselves, write reports, and divulge their research findings. The most well-known French think tanks are Fondation Jean Jaurès, Terra Nova, Fondapol, and the Montaigne Institute. Despite their 
admittance to the French policy advisory system, scholars continue to argue that French think tanks are not as important as their international equivalents, especially those operating in the English-speaking world (Campbell \& Pedersen, 2014).

\subsection{The Characteristics and Visibility of French Political Science}

In 2014, French political science was portrayed as a 'rare discipline' by the Ministry of Research and Higher Education (Blaise et al., 2014). In the 2018 survey that provided the data for this book, some 500 political scientists were permanently employed in France. Basically, they may be divided into two categories. The first is that of the teacher-researchers (enseignant-chercheur), who hold positions of assistant/associate or full professor. They either work in the Institutes of Political Science (IEP) or at a university, although not necessarily in fully-fledged political science departments. In France, the position of full professor of political science is much sought after and is subject to candidates passing a national exam (Agrégation de science politique) presided over by a jury of peers. Very few positions are available at each exam session and only for specific locations (due to vacancies, for example). Opinion on this exam is divided between those in favour of it, who see it as a means of guaranteeing the discipline its due recognition and protection, and those who are against it and dispute its meritocratic nature (supposed to counter tendencies like localism). Proponents push for further institutionalization, while opponents insist on its selection biases (gender and national biases) and on the universities' loss of power to hire staff locally and choose their own personnel (Musselin, 2019: 201-210). The second category is that of CNRS researcher. This position involves conducting research full-time, with a limited teaching load. Researchers are under contract with the CNRS or foundations such as the National Political Science Foundation (FNSP). In total, French political science teaching and research is run by approximately 130 full professors, 240 assistant and associate professors, and 120 CNRS researchers (Roux, 2018). Compared to other disciplines such as law, economics, or sociology, this limited number of academics spread across the country and working in various different subfields (of which political sociology and policy studies are the dominant ones) does not contribute to the visibility of the discipline (Déloye, 2012). The French 
public still sees Sciences Po as an 'elitist' school located in the capital, rather than a scientific discipline as such.

In order to examine and understand the viewpoints and conduct of the community of academic political scientists in France with regard to their advisory capacities and their exposure, data taken from the international survey of political scientists have been used. The survey response rate in France was $22 \%$, that is, 122 political scientists completed the questionnaire. The majority of the targeted scholars are tenured. The average age of those political scientists who responded to the survey was 50. This tends to reflect the tenured, mainly permanent positions of those scholars concerned. The gender distribution was $59 \%$ male and $35 \%$ female, while some respondents preferred not to disclose this factor. The most common subfields within the main discipline of political science indicated by the respondents were general political science $(49 \%)$, public policy $(32 \%)$, public administration (13\%), and social policies and welfare (12\%). This illustrates the emergence of subfields in French political science.

\subsection{Descriptive Analysis of the Survey Data}

This part examines the commitment to policy advice by considering the underlying normative views, reported advisory activities, advice recipients, and levels of governance, together with the channels of advice delivery.

\subsubsection{Normative Attitudes Towards Advisory Activities and Involvement in Public Debate: A Taste for Engagement}

Table 7.1 shows that political scientists display a mostly positive attitude towards participation in advisory activities and public debate, provided that ideas are first developed and tested within the academic sphere (around $55 \%$ of them thought this). The surveyed political scientists either fully or somewhat agree to their direct or indirect involvement in policy-making.

Participation in public debate is also valued by political scientists in France, a country where historically speaking there has been a significant orientation towards societal engagement in the social sciences and humanities (Chabal, 2017). Intellectuals such as Pierre Bourdieu, Michel Foucault and Raymond Aron were prominent participants in public debates. Some of those figures are still major, highly venerated, authoritative sources of inspiration for contemporary social and political scientists 
Table 7.1 Normative views on policy advice and involvement in public debate-France

\begin{tabular}{|c|c|c|c|c|c|}
\hline & $\begin{array}{l}\text { Fully } \\
\text { agree }\end{array}$ & $\begin{array}{l}\text { Somewhat } \\
\text { agree }\end{array}$ & $\begin{array}{l}\text { Somewhat } \\
\text { disagree }\end{array}$ & $\begin{array}{l}\text { Fully } \\
\text { disagree }\end{array}$ & $\begin{array}{l}\text { No } \\
\text { response }\end{array}$ \\
\hline $\begin{array}{l}\text { Political scientists should become } \\
\text { involved in policy-making }\end{array}$ & 13.1 & 44.3 & 27.1 & 7.4 & 8.2 \\
\hline $\begin{array}{l}\text { Political scientists have a } \\
\text { professional obligation to engage in } \\
\text { public debate }\end{array}$ & 11.5 & 27.9 & 36.9 & 18.0 & 5.7 \\
\hline $\begin{array}{l}\text { Political scientists should provide } \\
\text { evidence-based knowledge and } \\
\text { expertise outside academia but not } \\
\text { be directly involved in } \\
\text { policy-making }\end{array}$ & 15.6 & 44.3 & 27.9 & 1.6 & 10.7 \\
\hline $\begin{array}{l}\text { Political scientists should refrain } \\
\text { from direct engagement with policy } \\
\text { actors }\end{array}$ & 4.1 & 12.3 & 40.2 & 33.6 & 9.8 \\
\hline $\begin{array}{l}\text { Political scientists should engage in } \\
\text { public debate since this is part of } \\
\text { their role as social scientists }\end{array}$ & 39.3 & 52.5 & 4.9 & 0.8 & 2.5 \\
\hline $\begin{array}{l}\text { Political scientists should engage in } \\
\text { media or political advisory activities } \\
\text { only after testing their ideas in } \\
\text { academic outlets }\end{array}$ & 28.7 & 36.1 & 17.2 & 7.4 & 10.7 \\
\hline $\begin{array}{l}\text { Political scientists should engage in } \\
\text { public debate because this helps } \\
\text { them to expand their career options }\end{array}$ & 1.6 & 18.9 & 33.6 & 35.3 & 10.7 \\
\hline
\end{tabular}

Note: Question: 'To what extent do you agree with the following statements?'; including only those respondents who indicated 'fully agree' or 'somewhat agree'.

Source: ProSEPS survey data.

(François \& Magni-Berton, 2015). The survey results resonate well with this appeal for social engagement, since a positive view of participation in public debate seems to derive more from what respondents perceive to be the classical role of a social scientist (92\%) than from any strict professional obligations or as a way of furthering a career (see Table 7.2). Among the reasons given for involvement in advisory activities, an academic's professional career or financial gain seems to be much less important than the commitment to making a genuine contribution to society. 
Table 7.2 Intrinsic and extrinsic motives for engaging in policy advisory and consulting activities-France

\begin{tabular}{lclccc}
\hline & $\begin{array}{l}\text { Not } \\
\text { important } \\
\text { at all }\end{array}$ & $\begin{array}{l}\text { Somewhat } \\
\text { unimportant }\end{array}$ & $\begin{array}{l}\text { Somewhat } \\
\text { important }\end{array}$ & $\begin{array}{l}\text { Extremely } \\
\text { important }\end{array}$ & $\begin{array}{l}\text { No } \\
\text { response }\end{array}$ \\
\hline $\begin{array}{l}\text { I like to stay active } \\
\text { minded }\end{array}$ & 5.7 & 14.7 & 32.8 & 11.5 & 35.2 \\
$\begin{array}{l}\text { It helps advance my } \\
\text { academic career }\end{array}$ & 43.4 & 17.2 & 0.8 & 1.6 & 36.9 \\
$\begin{array}{l}\text { It helps expand my } \\
\text { career options and } \\
\text { provides alternative }\end{array}$ & 34.4 & 20.5 & 5.7 & 3.3 & 36.1 \\
$\begin{array}{l}\text { sources of finance } \\
\text { Engagement in } \\
\text { advisory or consulting }\end{array}$ & 27.0 & 14.7 & 17.2 & 3.3 & 37.7 \\
$\begin{array}{l}\text { activities is part of my } \\
\text { professional duty }\end{array}$ & & & & & \\
$\begin{array}{l}\text { I like to make a } \\
\text { contribution to society }\end{array}$ & 2.46 & 2.46 & 32.79 & 27.05 & 35.25 \\
\hline
\end{tabular}

Note: Question: 'How important are the following reasons for your engagement in advisory or consulting activities?'; the results only include those respondents who indicated 'fully agree' or 'somewhat agree'.

Source: ProSEPS survey data.

\subsubsection{Types of Advisory Activity}

The normative position towards advisory activities and engagement may lead us to expect the broad use of the range of activities concerned. However, this appears less true of political scientists in France. There is even a discrepancy between attitudes and actual advisory activities, as shown in Table 7.3. Frequencies of specific types of activity are low. Most of the respondents engage in such activities either on a yearly basis, less frequently, or never at all. It is clear that, in general, French political scientists are not particularly active advisers.

Regardless of the low degree of involvement in advisory activities, the most popular such activities are the analysis of the causes and consequences of policy problems and the provision of data and facts. Evaluating policies is less frequently engaged in, as are offering advice and consultancy services, and making recommendations on policy alternatives. Offering normative judgements and conducting forecasts and polls are the least commonly found forms of advisory activity. Almost $80 \%$ of the respondents are completely unfamiliar with this type of advising. In short, 
Table 7.3 Types of advisory activity—France

\begin{tabular}{|c|c|c|c|c|c|c|}
\hline & $\begin{array}{l}\text { At } \\
\text { least } \\
\text { once a } \\
\text { week }\end{array}$ & $\begin{array}{l}\text { At least } \\
\text { once a } \\
\text { month }\end{array}$ & $\begin{array}{l}\text { At } \\
\text { least } \\
\text { once a } \\
\text { year }\end{array}$ & $\begin{array}{l}\text { Less } \\
\text { frequently }\end{array}$ & Never & $\begin{array}{l}\text { No } \\
\text { response }\end{array}$ \\
\hline $\begin{array}{l}\text { I make value judgements and } \\
\text { normative arguments }\end{array}$ & 1.6 & 4.1 & 11.5 & 17.2 & 58.2 & 7.4 \\
\hline $\begin{array}{l}\text { I evaluate existing policies, } \\
\text { institutional arrangements, and } \\
\text { so on }\end{array}$ & 0.8 & 2.5 & 19.7 & 22.1 & 46.7 & 8.2 \\
\hline $\begin{array}{l}\text { I provide data and facts about } \\
\text { policies and political } \\
\text { phenomena }\end{array}$ & 0.8 & 4.9 & 32.0 & 19.7 & 37.7 & 4.9 \\
\hline $\begin{array}{l}\text { I analyse and explain the causes } \\
\text { and consequences of policy } \\
\text { problems }\end{array}$ & 1.6 & 9.8 & 34.4 & 17.2 & 30.3 & 6.6 \\
\hline $\begin{array}{l}\text { I offer consultancy services and } \\
\text { advice and make } \\
\text { recommendations on policy } \\
\text { alternatives }\end{array}$ & 0.8 & - & 8.2 & 20.5 & 61.5 & 9.0 \\
\hline $\begin{array}{l}\text { I make forecasts and/or carry } \\
\text { out polls }\end{array}$ & 0.8 & - & 4.1 & 4.9 & 79.5 & 10.7 \\
\hline
\end{tabular}

Note: Question: 'How often, on average, during the last three years, have you engaged in any of the following advisory activities with policy actors (policymakers, ministry officials, interest groups, political parties, etc.)?'; including only those respondents who indicated 'at least once per year', 'once per month', or 'once per week'.

Source: ProSEPS survey data.

political scientists tend to refrain from making recommendations and propositions (which in their eyes could be tantamount to engagement) but are less apprehensive about performing diagnostics and providing mere knowledge, facts, and data. While French political scientists may 'preach' the importance of advisory roles, they do not actually practice very many of them.

\subsubsection{Substantive Topics of Advice}

When political scientists engage in advisory activities, their advice can cover various subject matters and domains. Table 7.4 shows that the most common topics with regard to which advice is sought and given are matters of government and public administration (including electoral reform), 
Table 7.4 Substantive areas of policy advice-France

\begin{tabular}{|c|c|c|c|}
\hline Substantive area of policy advice & $\%$ & Substantive area of policy advice & $\%$ \\
\hline $\begin{array}{l}\text { Macroeconomics, monetary } \\
\text { policy, industrial policy }\end{array}$ & 2.46 & Social welfare & 12.30 \\
\hline $\begin{array}{l}\text { Civil rights, political rights, } \\
\text { gender issues }\end{array}$ & 14.75 & Crime, Law \& Order & 2.46 \\
\hline Health & 6.56 & $\begin{array}{l}\text { Domestic trade, commerce, the } \\
\text { financial sector }\end{array}$ & 0 \\
\hline Transportation & 2.46 & Defence & 7.38 \\
\hline Labour & 4.10 & $\begin{array}{l}\text { Technology (including } \\
\text { telecommunications) }\end{array}$ & 4.92 \\
\hline Education & 5.74 & Foreign trade & 0.82 \\
\hline Environment & 9.84 & $\begin{array}{l}\text { International affairs, development aid, } \\
\text { the EU }\end{array}$ & 18.03 \\
\hline Energy & 4.92 & $\begin{array}{l}\text { Government and public administration } \\
\text { organization, electoral reforms }\end{array}$ & 19.67 \\
\hline $\begin{array}{l}\text { Immigration, integration, } \\
\text { ethnic minorities }\end{array}$ & 14.75 & Public works, town planning & 2.46 \\
\hline Agriculture, food policy & 0 & Culture & 5.74 \\
\hline Housing & 1.64 & & \\
\hline
\end{tabular}

Note: Question: 'With which substantive policy areas is your advice concerned?'

Source: ProSEPS survey data.

international affairs and the European Union, civil and political rights including gender issues, social welfare, and immigration. All of these topic categories reflect the expertise of the survey's respondents.

\subsubsection{Recipients of Political Scientists' Advice and Levels of Governance}

In the last three years, the most recurrent beneficiaries of political scientists' advice in France have been both civil society organizations and citizens groups (47.5\%) and civil servants $(41 \%)$, as Table 7.5 shows. The tendency to work with associations and other societal actors is once again evident. This reflects the aforementioned move towards a greater degree of pluralism and the increasingly participatory nature of the policy advisory system. A good example of this transformation is the emergence of participatory and deliberative sciences. Indeed, a number of academics have responded to increase demand within public authorities for expertise on participatory matters, by providing a series of specialized and 
Table 7.5 Recipients of advice-France

\begin{tabular}{ll}
\hline Recipients & Percentage \\
\hline Other civil society organizations and citizens groups & 47,5 \\
Civil servants & 41 \\
Think tanks & 29.5 \\
MPs & 23.8 \\
International organizations & 23.8 \\
Members of government & 22.9 \\
Political parties & 21 \\
Advisory bodies & 18.8 \\
Interest groups in the private and corporate sectors & 6.6 \\
\hline
\end{tabular}

Note: Question: 'With which actors did you engage in knowledge exchange, advisory or consulting activities during the last three years?'

Source: ProSEPS survey data.

standardized 'goods' and 'services', thus establishing what is now considered a market in its own right (Blatrix, 2012). Numerous political scientists, as scholars of participation, now monopolize these issues, with their expertise widely recognized; in this they have been aided by organizations and platforms such as the GIS Democracy and Participation or by think tanks such as 'Décider Ensemble'. Political scientists now take part in the construction, realization, and evaluation of participatory devices and experiences, together with actors from several tiers of government and with various organizations and associations.

The relative prominence of civil servants as recipients of political science advice is in keeping with the expectation of a rather 'impermeable' and 'independent' public administration, at least in its Napoleonic form, with inherently selective co-option mechanisms only working for certain political scientists rather than for a large majority of them. Whether or not such recipients are senior civil servants operating at the core or in the top layers of the administrative system is another question, the answer to which would require more detailed data.

Advice tends to a lesser extent to filter through to political actors as well. MPs tend to receive advice slightly more often $(23.8 \%)$ than members of government $(22.9 \%)$ or political party organizations $(21 \%)$ do. It appears that most academic political scientists remain somewhat removed from politics and party political organizations. The difficulty of accessing central government (especially ministers and their entourage), as well as 
MPs and aides, possibly due to a perceived lack of openness and receptiveness on such politicans' part, may explain this. Advice from Europeanists and scholars of international relations and area studies, whose fields of expertise are not confined to national boundaries, may filter through to international and supranational organizations. France has clearly witnessed a limited internationalization of advice; offering additional windows of opportunity for political scientists $(23.8 \%)$, but this is probably constrained by the frequent use of French as a working and publishing language.

The rise and affirmation of think tanks may also have impacted French political scientists, since a considerable number of them $(30 \%)$ have provided advice to such bodies. Furthermore, advisory ties with formal advisory bodies (18.8\%) and with interest groups in the private and corporate sector $(6.6 \%)$ are somewhat weak. This contrasts with the relative prominence of civil society organizations and citizen groups. Political scientists distrust interest groups of the corporate sector, possibly sharing this distrust with bureaucratic actors and the broader French public. A relatively limited inclusion of political scientists in the activities of the many consultative and advisory organs was expected. A rapid screening of the identities of the CESE's associates, of the individuals officially consulted during the CESE's hearings or called upon to participate in the activities of advisory bodies, would tend to confirm this expectation. Political scientists also have a marginal part to play in negotiations with social partners and stakeholders.

The levels at which political scientists offer their expertise, as displayed in Table 7.6, tend to reflect the centralized nature of the French political and administrative system. It directs political science advice towards national actors, rather than subnational or international ones. This is not a static situation however, as in decentralization processes mean that subnational levels are now becoming more important, and now represent potential entry points to the advisory sphere for political scientists as well. Sub-national levels include regional tiers, départements, cities, and metropolitan areas of governance.

\subsubsection{Channels of Advice Delivery}

As shown in Table 7.7, political scientists tend to opt for academic publications, traditional media articles, and training courses for practitioners when offering their advice and expertise. They do this mostly on an annual basis. Here again, research reports and policy reports, briefs, or memo are 
Table 7.7 Channels of advice-France

\begin{tabular}{|c|c|c|c|c|c|c|}
\hline & $\begin{array}{l}\text { At least } \\
\text { once a } \\
\text { week }\end{array}$ & $\begin{array}{l}\text { At least } \\
\text { once a } \\
\text { month }\end{array}$ & $\begin{array}{l}\text { At } \\
\text { least } \\
\text { once a } \\
\text { year }\end{array}$ & $\begin{array}{l}\text { Less } \\
\text { frequently }\end{array}$ & Never & $\begin{array}{l}\text { No } \\
\text { response }\end{array}$ \\
\hline $\begin{array}{l}\text { Publications (e.g. books, } \\
\text { articles) }\end{array}$ & 2.5 & 4.9 & 35.2 & 11.5 & 13.9 & 32.0 \\
\hline Research reports & 0.8 & 2.5 & 18.0 & 33.6 & 11.5 & 33.6 \\
\hline $\begin{array}{l}\text { Policy reports/policy briefs / } \\
\text { memos }\end{array}$ & - & 2.5 & 10.7 & 21.3 & 27.0 & 38.5 \\
\hline Traditional media articles & 2.5 & 6.6 & 29.5 & 14.7 & 13.1 & 33.6 \\
\hline $\begin{array}{l}\text { Blog pieces or social media } \\
\text { articles/pieces }\end{array}$ & 0.8 & 5.7 & 10.7 & 12.3 & 32.8 & 37.7 \\
\hline $\begin{array}{l}\text { Training courses for policy } \\
\text { actors, administrative } \\
\text { organizations, or other actors } \\
\text { and stakeholders }\end{array}$ & 0.8 & 4.9 & 22.9 & 17.2 & 22.1 & 32.0 \\
\hline
\end{tabular}

Note: Question: 'Over the past three years, how frequently have you used any of the channels below to provide policy advice and/or consulting services?'; including only those respondents who indicated 'at least once per year', 'once per month', or 'once per week'.

Source: ProSEPS survey data.

Table 7.6 Governance levels of advice-France

\begin{tabular}{lc}
\hline & Percentage \\
\hline National level & 43.4 \\
Sub-national level & 30.3 \\
Transnational or international level & 13.1 \\
EU level & 9.0 \\
\hline
\end{tabular}

Note: Question: At which level of governance did you engage most frequently in policy advice or consulting activities during the last three years?

Source: ProSEPS survey data.

not common, and this once again indicates a certain distance from policymakers or a certain reluctance to produce and divulge content that could be very useful to such recipients. This may also be the result of a lack of demand for such advice from the decision-makers themselves, who may consider that the state expertise apparatus and the grand corps sufficiently already cover their needs. Only a minority of French political scientists regularly write blogs or social media articles, even if the time required to 
produce such is less than that needed to write more traditional research and academic items such as articles and research reports.

\subsection{Capturing Views and Activities in Main Policy Advisory Roles}

Using the typology of advisory profiles presented in Chap. 2, it appears that the pure academic is not the most common profile among the survey's respondents, meaning that despite the limited frequency of advice-giving, there is no evident retreating behind the walls of academia in French political science. Table 7.8 displays the main findings in this regard. Just under $28 \%$ of the political scientists who responded to the survey questionnaire do not engage in any advisory activity and thus can be classified as pure academics. This is also the category with the highest female presence $(44 \%)$, while the proportion of female scholars decreases as role types involve increasing advisory activities. When French political scientists start to take part in advisory activities, even if not particularly frequently, they do so as experts, thus implying no explicit value judgements are given. The experts in our sample are also less advanced in terms of their academic careers and tend to be younger than their more outspoken colleagues. Opinionating scholars also are well represented and form a group which display normative views and include value judgements in the advisory content and some also engage in advocacy. This category of political scientists is also more widely present in the media. This may be related to the appreciation of social engagement, a certain critical stance towards government, and the quest for visibility, to be found among some political scientists.

Table 7.8 Proportions of advisory roles-France

\begin{tabular}{lrll}
\hline Types of advisor & Frequency & $\begin{array}{l}\text { Percentage in } \\
\text { France }\end{array}$ & $\begin{array}{l}\text { Percentage in overall European } \\
\text { sample }\end{array}$ \\
\hline Pure academic & 34 & 27.9 & 20.3 \\
Expert & 46 & 37.7 & 26.6 \\
Opinionating & 39 & 32.0 & 48.7 \\
scholar & & & \\
Public intellectual & 3 & 2.5 & 4.4 \\
Total & 122 & 100.0 & 100.0 \\
\hline
\end{tabular}

Source: ProSEPS survey data. 


\subsection{Institutional Reform and Involvement in Public Debate}

On 3 July 2017, the newly elected French president Emmanuel Macron delivered a speech to MPs from the National Assembly and the Senate, gathered together at the meeting of Congress in Versailles, in which he set out his priorities for the presidential term. Reforming institutions had been one of his electoral pledges and a project he and others considered of prime importance. The last reform of this kind had been made in 2008 under President Nicolas Sarkozy, who intended to modernize the institutions, notably by curbing executive powers to the benefit of national parliament. This previous reform had consisted in a major review of the French Constitution. In its own way, Macron's ambition to re-design institutions targeted the country's parliament, although the CESE and other institutions were also concerned as well. Macron's plan sought to increase the quality of political representation and to improve the way institutions would operate.

He announced approximately 30 measures as part of the reform, including a reduction in the number of MPs of both the lower and upper houses by between $25 \%$ and $33 \%$ and a degree of proportional representation (10-25\% of MPs were to be elected under a system of PR). After the President had set out his intentions, a public debate ensued: opinion polls indicated strong public support for both measures, while certain political figures taking part in the debate were more sceptical. After examining and considering Macron's proposed reforms, the chairs of the two assemblies responded to the proposal and disagreements and red lines began to surface, particular in the Senate during the first half of 2018.

Political scientists in academia could potentially have a voice, deliver knowledge and facts, and formulate their advice and recommendations on the specific reform proposals. Some of them have seized this opportunity, as our case-study reform was a very good opportunity for political science to have some impact, especially through the involvement of scholars specialized in parliamentary institutions or the electoral system. At their initiative, they formulated contributions and chose the topics they wanted to speak about. Some focused on the proportional representation aspect and potential reform of the voting system, while others focused more on the potential reduction in the number of MPs. Numbers triggered attention in the debate, focusing in this case on the right combination of proportional representation and the ideal number of representatives in the two chambers of parliament. 
Political scientists used different channels through which to present and divulge their advice. They wrote several reports published by think tanks or research institutes, together with articles in the specialized press or in traditional media outlets and also engaged in blogging activities. The reports proved to be rather effective and convincing, especially one which specifically addressed the issue of the reduction in the number of parliamentarians (Ehrhard \& Rozenberg, 2018).

The consequences of the reform were somewhat uncertain in many ways, specifically with regard to the number and size of constituencies, to the internal diversity and pluralism within assemblies, and to budgetary costs. In contributing to the debate, political scientists examined and envisioned the consequences and risks of the reform, using 'what-if' simulations (e.g. Cohendet et al., 2018). At times, they also placed the French parliament in a broader international context, using figures, informative tables, and political science literature to do so. However, the reports were not really 'neutral', insofar as they made explicit or implicit recommendations or directly criticized the reform plans. One of the reports, probably the most influential one (Ehrhard \& Rozenberg, 2018), examined the main arguments put forward by the government and the majority in support of the reform and challenged and debunked each and every one of them on empirical grounds.

The reports and statements made by political scientists in the debate did not result in any significant change in the content of the reform, but they did affect the terms of the debate. In the virtual absence of other contributions from scholars or analysts, opposition MPs fighting against the proposed reduction of MPs used the political scientists' analyses in order to adopt an evidence-based position against the reform plans. The release of the reports was well timed, coming just before the reform's examination in parliamentary commissions or plenary sessions. Furthermore, the authors of the reports and statements were not unknown to the parliamentary recipients of the advice as a result of past advisory involvement. This made political scientists more trustworthy in the eyes of a number of MPs.

\subsection{Conclusion}

In a manner proportionate to its limited size, its organization, and its place within the sphere of higher education and research and in society as a whole, French academic political science has a certain advisory role to play. 
Political science has engaged in infrequent, but at times effective and lasting, ventures within the framework of the national policy advisory system. The advice flowing from academics to policymakers and civil society has enjoyed the benefit of certain favourable conditions, which have partly offset the macro-, meso-, and micro-level constraints on advice formulation, dissemination, and utilization.

First and foremost, there has been a substantial change in the participation of political scientists who, after aligning with civil society, societal actors, organized civil society and associations, may be benefiting from their increasing importance to the policy advisory system. This is even more so because many political scientists seem to have a propensity towards such societal involvement. French political science may (re-)acquire broader relevance in this way.

Furthermore, the civil service does not seem impervious to seeking and/or receiving advice from political scientists. Therefore, a degree of cooperation between the administrative and academic spheres exists. In a way, a market for social science still exists, and as such this affects political science as well (Lecas, 1991: 329-330). The 'need to know' in sectors and domains where internal, state, or administrative expertise is absent, less incisive, or deficient may create and sustain advisory connections involving political scientists. Political scientists, either individually or collectively, may sometimes be pro-active in anticipating the needs of policymakers too, creating interfaces between the academic community and public authorities.

Contrary to the more secluded central decisional milieu, subnational tiers of government and the ecosystems that have come to surround them are now accessible venues. This situation was hardly acknowledged at all in earlier accounts of the discipline. The different degrees of advisory involvement at national and sub-national levels is becoming less pronounced. Moreover, ties with peripheral actors such as think tanks, boundary organizations for advice and research platforms concerned with the divulgation of research findings and their interpretation, may critically enhance the advisory role of academic political science. The willingness and ability of individual scholars to employ a wide array of channels, formats, and strategies of diffusion will also help political science gain a more prominent position in France's policy advisory system.

In many respects, French political science has evolved and progressed significantly since the late 1940s. Gaining greater relevance in the eyes of decision-makers at all levels is another key challenge it faces, in a country 
where the central State's own capacity and expertise are considered by many a very strong asset. Some political scientists are already advocating a change of mindset and practices to break down barriers and suggest ways forward, such as through the development of hybrid profiles and the cultivation of trust and shared understanding between the social sciences research community and the country's political decision-makers (e.g. Cagé, 2019). The question remains as to whether French political science will play a more important advisory role in French political policy in the near future.

\section{REFERENCES}

Bellon, A., Collas, T., \& Mayance, P. (2018). Boulevards et chemins de traverse : les carrières des collaborateurs de l'exécutif (2012-2014). Revue française d'administration publique, 168(4), 875-889.

Berrebi-Hoffmann, I., \& Grémion, P. (2009). Élites intellectuelles et réforme de l'État : Esquisse en trois temps d'un déplacement d'expertise. Cabiers internationaux de sociologie, 126(1), 39-59.

Bezès, P. (2012). État, experts et savoirs néo-managériaux : Les producteurs et diffuseurs du New Public Management en France depuis les années 1970. Actes de la recherche en sciences sociales, 193(3), 16-37.

Bezès, P., \& Le Lidec, P. (2011). Steering from the Centre in France in the 2000s: When Reorganizations Meet Politicization. In C. Dahlström, G. B. Peters, \& J. Pierre (Eds.), Steering from the Centre. Strengthening Political Control in Western Democracies (pp. 27-53). University of Toronto Press.

Bezès, P., Chauvière, M., Chevallier, J., de Montricher, N., \& Ocqueteau, F. (2005). L'État à l'épreuve des sciences sociales: La fonction recherche dans les administrations sous la Ve République. La Découverte.

Biland, E., \& Gally, N. (2018). Civil servants and policy analysis in Central Government. In C. Halpern, P. Hassenteufel, \& P. Zittoun (Eds.), Policy Analysis in France (pp. 101-118). Policy Press.

Blaise, F., Mutzenhardt, P., \& Roussel, G. (2014). Disciplines rares : rapport à Madame la Secrétaire d'Etat à l'Enseignement Supérieur et la Recherche. 2014-12-16. Retrieved September 10, 2020, from https://cache.media. enseignementsup-recherche.gouv.fr/file/Actus/62/1/rapport_final_mission_ disciplines_rares_16-12-2014_404621.pdf

Blatrix, C. (2012). Des sciences de la participation : paysage participatif et marché des biens savants en France. Quaderni, 79(3), 59-80.

Boncourt, T. (2011). L'internationalisation de la science politique : une comparaison franco-britannique : (1945-2010), thèse de doctorant en Science politique. 
Boussaguet, L., Jacquot, S., Ravinet, P., \& Muller, P. (2015). Une French touch dans l'analyse des politiques publiques? Presses de Sciences Po.

Cagé, A. (2019). Faire tomber les murs entre intellectuels et politiques. Fayard.

Campbell, J. L., \& Pedersen, O. K. (2014). The national origins of policy ideas: Knowledge regimes in the United States, France, Germany, and Denmark. Princeton University Press.

Chabal, E. (2017). Les intellectuels et la crise de la démocratie. Pouvoirs, 161(2), 109-120.

Cohendet, M-A., Lang, J., Laslier, J-F., Pech, T., \& Sawicki, F. (2018). Une dose de proportionnelle": pourquoi, comment, laquelle ? Rapport Terra Nova, 2018-03-19.

Cornut, J., \& Battistella, D. (2013). Des RI françaises en émergence : Les internationalistes français dans le sondage TRIP 2011. Revue française de science politique, 63(2), 303-336.

de Baecque, F. (1981). L'interpénétration des personnels administratifs et politiques. In F. de Baecque and J-L. Quermonne (Eds.), Administration et politique sous la Cinquième République (pp. 19-60). FNSP.

Déloye, Y. (2012). Éléments pour une morphologie des politistes français au vingt et unième siècle. Politique et Sociétés, 31(3), 109-126.

Déloye, Y., \& Mayer, N. (2008). French Political Science at a Turning Point. French Politics, 6, 280-301.

Déloye, Y., \& Mayer, N. (2019). Les trois défis de la science politique française : Retour sur la période 1968-2018. Idées économiques et sociales, 195(1), 28-39.

Ehrhard, T., \& Rozenberg, O. (2018). La réduction du nombre de parlementaires est-elle justifiée ? Une évaluation ex-ante, Sciences Po LIEPP Working Paper $\mathrm{n}^{\circ} 75,2018-02-06$.

Favre, P. (1989). Naissances de la science politique en France. 1870-1914. Fayard.

Favre, P. (2005). Épilogue. Le silence de la science politique. In P. Favre (Ed.), Comprendre le monde pour le changer : Épistémologie du politique (pp. 355-381). Presses de Sciences Po.

François, A., \& Magni-Berton, R. (2015). Que pensent les penseurs ? Les opinions des universitaires et scientifiques français. $\mathrm{PUG}$.

Gaïti, B., \& Scot, M. (2017). Une science sans savants : Les paradoxes de l'émergence de la science politique en France entre 1945 et 1968. Revue française de science politique, $67(1), 13-42$.

Gervais, J., \& Pierru, F. (2018). Management Consultants as policy actors. In C. Halpern, P. Hassenteufel, \& P. Zittoun (Eds.), Policy Analysis in France (pp. 175-190). Policy Press.

Grémion, C. (1982). Le milieu décisionnel central. In F. de Baecque and J-L. Quermonne (Eds.), Administration et politique sous la Cinquième République (pp. 205-224). FNSP. 
Grossman, E. (2010). Les stratégies de publication des politistes français. Facteurs d'unité et de diversité. Revue française de science politique, 60(3), 565-585.

Grossman, E., \& Saurugger, S. (2004). Challenging French Interest Groups: The State, Europe and the International Political System. French Politics and Society, 2(2), 203-220.

Halpern, C., Hassenteufel, P., \& Zittoun, P. (2018). Policy Analysis in France. Policy Press.

Hassenteufel, P. (1990). Où en est le Paradigme corporatiste ? Politix, 12, 75-81.

Hauchecorne, M., \& Penissat, E. (2018). The field of state expertise. In C. Halpern, P. Hassenteufel, \& P. Zittoun (Eds.), Policy Analysis in France (pp. 191-207). Policy Press.

Jobert, B., \& Muller, P. (1987). L'Etat en Action. Politiques Publiques et Corporatismes. Presses Universitaires de France.

Lacouette-Fougère, C., \& Lascoumes, P. (2013). L'évaluation : un marronnier de l'action gouvernementale ? Revue française d'administration publique, $148(4), 859-875$.

Le Galès, P. (2011). Public policy research: deconstructing the French touch. Critical Policy Studies, 5(2), 201-207.

Le Galès, P., \& Hassenteufel, P. (2018). The academic world of French policy studies: training, teaching and researching. In C. Halpern, P. Hassenteufel, \& P. Zittoun (Eds.), Policy Analysis in France (pp. 295-312). Policy Press.

Lecas, J. (1991). French political science: some problems and difficulties in the social organization of the discipline. European Journal of Political Research, 20, 323-340.

Mathiot, P., \& Sawicki, F. (1999). Les membres des cabinets ministériels socialistes en France (1981-1993) : recrutement et reconversion. Caractéristiques sociales et filières de recrutement. Revue française de science politique, 49(1), 3-29.

Musselin, C. (2019). Propositions d'une chercheuse pour l'Université. Presses de Sciences Po.

Ongaro, E. (2010). The Napoleonic Administrative Tradition and Public Management Reform in France, Greece, Italy, Portugal and Spain. In M. Painter \& B. G. Peters (Eds.), Tradition and Public Administration (pp. 174-190). Palgrave Macmillan.

Painter, M., \& Peters, B. G. (2010). Administrative Traditions in Comparative Perspective: Families, Groups and Hybrids. In M. Painter \& B. G. Peters (Eds.), Tradition and Public Administration (pp. 19-30). Palgrave Macmillan.

Rosser, C., \& Mavrot, C. (2017). Questioning the Constitutional Order: A Comparison of the French and the U.S. Politics-Administration Dichotomy Controversies After World War II. The American Review of Public Administration, 47(7), 737-751.

Roux, C. Bilan de synthèse de la campagne de recrutement des maîtres de conférences et professeurs en science politique lors de la session synchronisée 2018. Lettre de l'OMASP n ${ }^{\circ} 13$, October 2018. 
Rozenberg, O., \& Surel, Y. (2018). Beyond weakness: policy analysis in the French Parliament. In C. Halpern, P. Hassenteufel, \& P. Zittoun (Eds.), Policy Analysis in France (pp. 137-154). Policy Press.

Schmidt, V. A. (1999). Privatization in France: The Transformation of French Capitalism. Environment and Planning C: Government and Policy, $17(4), 445-461$.

Schultz, M., Bressers, D., van der Steen, M., \& van Twist, M. (2015). Internal advisory systems in different political-administrative regimes: exploring the fit of configuration, administration and composition of internal advisory systems in France, Germany, Sweden, the Netherlands and the United Kingdom. Prepared for the International Conference on Public Policy, Milan, 1-4 July.

Smith, A. (2020). A Glass Half Full: The Growing Strength of French Political Science. European Political Science., 19(2), 253-271.

Spenlehauer, V. (1999). Intelligence gouvernementale et sciences sociales. Politix, 12(48), 95-128. https://doi.org/10.3406/polix.1999.1809

Szarka, J. (2002). The Shaping of Environmental Policy in France. Berghahn Books. Woll, C. (2009). The Demise of Statism? In S. Brouard, A. Mazur, \& A. M. Appleton (Eds.), The French Fifth Republic at Fifty: Beyond Stereotypes (pp. 226-246). Palgrave Macmillan.

\section{WeBpages}

https://www.vie-publique.fr/eclairage/22018-reforme-de-letat-reduction-dunombre-des-commissions-consultatives

Open Access This chapter is licensed under the terms of the Creative Commons Attribution 4.0 International License (http://creativecommons.org/licenses/ by $/ 4.0 /$ ), which permits use, sharing, adaptation, distribution and reproduction in any medium or format, as long as you give appropriate credit to the original author(s) and the source, provide a link to the Creative Commons licence and indicate if changes were made.

The images or other third party material in this chapter are included in the chapter's Creative Commons licence, unless indicated otherwise in a credit line to the material. If material is not included in the chapter's Creative Commons licence and your intended use is not permitted by statutory regulation or exceeds the permitted use, you will need to obtain permission directly from the copyright holder.

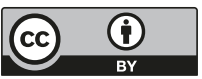

